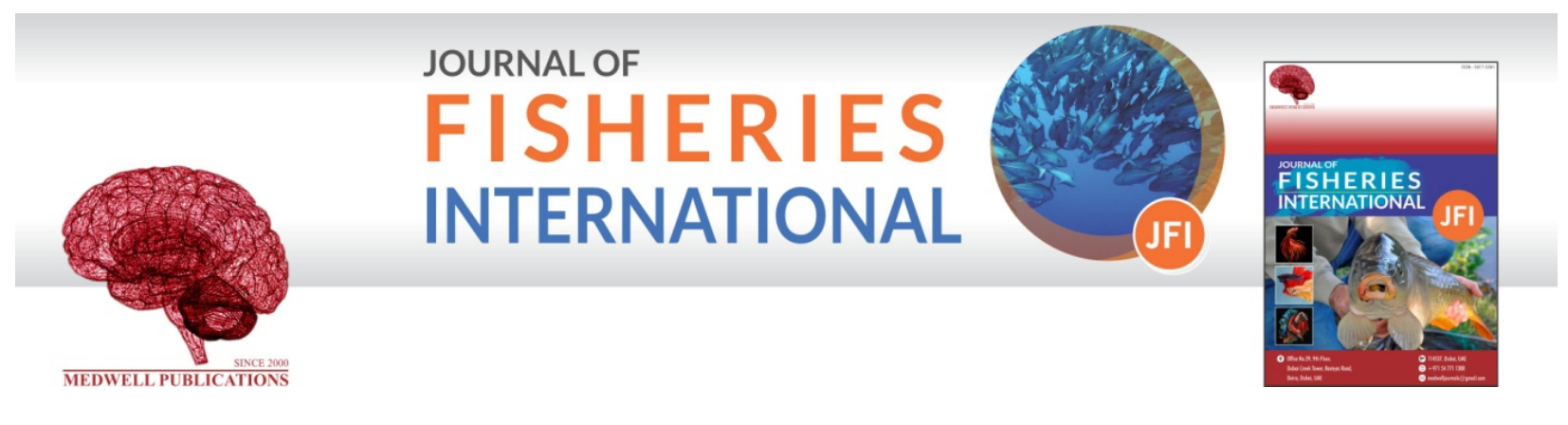

\title{
Phytoplankton Zooplankton Interrelationship Between Two Ponds and Effect of Seasonal Fluctuations on their Abundance
}

${ }^{1}$ S.M. Majharul Islam, ${ }^{2} \mathrm{Md}$. Jahangir Alam and ${ }^{1} \mathrm{Md}$. Sulaiman

${ }^{1}$ Department of Fisheries Management, Faculty of Fisheries, Bangladesh Agricultural University, 2202 Mymensingh, Bangladesh

${ }^{2}$ Department of Fisheries Management, Faculty of Fisheries, Patuakhali Science and Technology Univerasity, 8602 Dumki, Bangladesh

Key words: Physico-chemical parameters, phytoplankton, zooplankton, abundance, pond

\section{Corresponding Author:}

S.M. Majharul Islam

Department of Fisheries Management, Faculty of Fisheries, Bangladesh Agricultural University, 2202 Mymensingh, Bangladesh

Page No.: 7-13

Volume: 15, Issue 1, 2020

ISSN: $1817-3381$

Journal of Fisheries International

Copy Right: Medwell Publcations
Abstract: Physico-chemical parameter and plankton such as phyto and zooplankton have been studied in selected two ponds in Dumkiupazila in Patuakhali district. Physico-chemical parameter plays a vital role in aquatic community. Their growth and productivity rate directly affected by those parameters. Phyto and Zooplankton that constitute an important food supplier of many omnivorous and carnivorous fishes. Moreover, it has a great impacts to control biological activity, oxidation and organic compounds. The study was carried out both culture and non-culture aquatic resource. There are about 4 groups of zooplankton where Copepoda (40.08\%), Maxillopoda (38.83\%), Malacostraca (16.29\%), Branchiopoda (4.8\%) and 10 groups of phytoplanktonwere identified where Bacillariophyceae (29.65\%), Euglenophyceae (1.34\%), Spirotrichea $(2.20 \%)$, Cyanophyceae $(25.88 \%)$, Surirellaceae (0.74\%), Chlorophyceae $(1.13 \%)$, Zygnematophyceae (3.30\%), Ulotrichaceae (10.85\%), Ulvophyceae (24.88\%). Nauplius (38.83\%) are the most abundant among all Zooplankton and Fragillaria (22.02\%) are most among all phytoplankton. Physico-chemical parameters has a great impacts on plankton abundance. Some physico-chemical parameters such as: temperature, transparency, dissolved oxygen, $\mathrm{pH}$, alkalinity, hardness, nitrate, ammonia were observed monthly. Mean values of water temperature $\left({ }^{\circ} \mathrm{C}\right)$, transparency $(\mathrm{cm})$, dissolved oxygen $\left(\mathrm{mg} \mathrm{L}^{-1}\right), \mathrm{pH}$, alkalinity, hardness, nitrate (mg L${ }^{-1}$ ) and ammonia $\left(\mathrm{mg} \mathrm{L}^{-1}\right)$ were $29.35 \pm 1.68$, $36.71 \pm 3.8,4.90 \pm 1.7,7.19 \pm 0.7,95.14 \pm 17.19,10.72 \pm 2.27$, $0.16 \pm 0.08$, respectively. Water temperature, ammonia, $\mathrm{pH}$ and phosphorus were optimum range in the investigation time. But the concentration of nitrate was so, 
high. Nitrate, ammonia and dissolve oxygen were responsible for water quality deterioration and great affect on the whole plankton production system. So, plankton abundance having a correlation with physic-chemical parameter and that has a diverse effect on the aquatic organisms.

\section{INTRODUCTION}

Physico-chemical parameter has a great role on water body and aquatic organisms. These parameters also have advantage indirectly to balance food chain and ecosystem. But this type of parameter largely depends on climate, region and geological variance. As an example we can say that, the parameter of fresh water body that may vary form marine water. A number of studies have been done by many researchers. Bhuiyan et al. ${ }^{[1]}$ observed the physico-chemical conditions in relation to meteorological conditions of a fish pond in Rajshahi. Phytoplankton and zooplankton are greatly influenced by seasonal variation and physic-chemical parameter. Moreover, plankton and physic-chemical parameter have a co-relationship and plankton survival rates largely depends on those factors. Changes in the physico-chemical parameters may positively or negatively affect the biota of water bodies in a number of ways such as their survival and growth rate and these may eventually result in disappearance of some species of organisms or its reproduction ${ }^{[2]}$.

Plankton has a great important role on water body basically as a food item of many fish species. The plankton community is comprised of the primary producers or phytoplankton and zooplankton; the secondary producers ${ }^{[3]}$. These types of plankton controls the food chain used as a primary or secondary producer. It is an integral component of fresh water body to maintain the food chain and also have quality and quantity criteria. It also indicates the water quality and succession of aquaculture operation. Their abundance may be vary from location to location according to water quality and parameters. A lot of number research activities have been done on fish ponds. Fakruzzaman et al. ${ }^{[4]}$ studied the zooplankton of some fish ponds in Barind Tract in relation to its physico-chemical variables. Biswas ${ }^{[5]}$ studied the limnology of three fish ponds in Rajshahi hatchery while Rahman et al. ${ }^{[6]}$ and Mumtazuddi et al. $\left.{ }^{[7}\right]$ worked on some fishpondsin Mymenshingh. According to Prasad and Singh ${ }^{[8]}$, the zooplankton forms the principal source of food for fish within the water body, zooplankton contributes about $82 \%$ of the food items of Anabas testudineus $^{[9]}, 32 \%$ of Notopterusnotopterus ${ }^{[10]}, 47.06 \%$ of Catlacatla and $6.37 \%$ of Labeorohita ${ }^{[1]}, 24.19 \%$ of Oreochromisnilotica ${ }^{[12]}, 38.5 \%$ of Rohteecotio ${ }^{[13]}$ and $30 \%$ of Mystusvittatus.

The purpose of this study is to develop and understanding the phytoplankton and zooplankton community, their abundance, distribution and interrelationship with physic-chemical parameter in the water body.

\section{MATERIALS AND METHODS}

Sample collection: The plankton sampling was carried out by plankton net in different location of two selected pond at different time. Then the collected sample were preserved in plastic bottle with \% formalin. The collected samples were taken Sedgewick Rafter Counter Cell (SRC) and which was brought under digital microscope (Optica Microscope Italy) and observed carefully. With the help of identified book the plankton were identified.

Plankton abundance is the number of individuals or cells per units of volume. The number of individual plankton was calculated under the following equation:

$$
\mathrm{K}=\frac{1}{\mathrm{~A}} \times \frac{\mathrm{B}}{\mathrm{C}} \times \frac{\mathrm{V}}{\mathrm{v}} \times \mathrm{n}
$$

Where:

$\mathrm{K}$ : Phytoplankton abundance (cell $\mathrm{m}^{-3}$ )

A : Volume of filtered water sample (2 L)

B : Total area/container area of Sedgewick rafter counting cell $(\mathrm{mL})$

C : Observed area $\left(\mathrm{mm}^{2}\right)$

$\mathrm{V}$ : Volume of filtered water $(1.5 \mathrm{~mL})$

$\mathrm{v}$ : Concentration volume of Sedgewick rafter counting cell $(\mathrm{mL})$

$\mathrm{n}$ : Number of observed phytoplankton

Some of the physico-chemical studies were done on the spot while others were done in laboratory. The ponds were flown at Dumki city beside the market. It is a perennial and shallow water body and holds average water body almost $1.5-2 \mathrm{~m}$ around the year. The ponds gets sunlight around the year and the bottom soil of which contains clay and the ponds are highly charged. Run off containing sewage, detergents, animal dung silt and decomposed of organic matter enrich the ponds with nutrients that supports the growth of aquatic macrophytes. These ponds are dewatered every year during the rainy season.

Temperature was measured by a centigrade thermometer. Transparency was measured by a Secchidisc while $\mathrm{pH}$. Dissolved Oxygen (DO) content of water was determined by DO meter (model-JENWAY-9015). Titrimetric methods was used to determine the alkalinity. Ammonia and nitrite were estimated using $\mathrm{HACH}$ water test kit.

Collection of samples and necessary preservation for various physico-chemical parameters and their estimation 
were carried out following Standard Methods ${ }^{[14]}$. Qualitative and quantitative analysis of both phyto and zooplankton were done following drop count method $^{[14]}$.

\section{RESULTS AND DISCUSSION}

Physico-chemical parameter and abundance of plankton (Phytoplankton and zooplankton) were shown at different table. Physico-chemical parameter that has a great effects on aquatic organisms. On the other hand, phytoplankton plays an important role as a primary producer and zooplankton as a primary consumer. Moreover, they also serve as a main food source of higher aquatic organisms. Zooplankton provides main food for fisher at all the stages of life and can also be used as indicators of the trophic status of water body. In physic-chemical parameter are shown below:

Water quality parameters: Water quality parameter is very essential to survive any kind of organisms in aquatic water body. Various types of parameter such as water temperature $\left({ }^{\circ} \mathrm{C}\right)$, Transparency $(\mathrm{cm})$, dissolves Oxygen $\left(\mathrm{mg} \mathrm{L}^{-1}\right), \mathrm{pH}$, Alkalinity $\left(\mathrm{mg} \mathrm{L}^{-1}\right)$, Hardness $\left(\mathrm{mg} \mathrm{L}^{-1}\right)$, nitrate- $\mathrm{N}\left(\mathrm{mg} \mathrm{L}^{-1}\right)$ and Ammonia $\left(\mathrm{mg} \mathrm{L}^{-1}\right)$ were measured during the investigation area which are shown in Table 1.

Water temperature: During the investigation area, water temperature was recorded with the help of thermometer. The temperature was varying between $27.5-30.5^{\circ} \mathrm{C}$ in different location and month to month during the study period. The highest temperature was measured in the month of July $\left(32.0 \pm 1.41^{\circ} \mathrm{C}\right)$ and the lowest temperature was in the month of October $\left(26.5 \pm 0.71^{\circ} \mathrm{C}\right)$.

Transparency: Transparency has a vital role in the open or semi-closed water body for fish culture due to remaining soil particle in suspended condition in water. For measuring the water transparency, secchi disk is used during the study period and the ranges of transparency were varied between $31.5-44 \mathrm{~cm}$ which in shown Table 1.
The highest value $(44.0 \pm 1.41)$ of transparency was recorded in the month of October and the lowest $(31.5 \pm 0.71)$ was measured in the month of June.

Dissolved oxygen: Dissolved oxygen is very important physical parameter for aquatic organisms both open, closed or semi-closed water body. This is measured by using a portable digital DO meter (DO 5509, AF. 11581, made in Taiwan) on the selected location. The ranges of dissolved oxygen were found more or less similar in different month at different time in the study area and it was varied between $4.26-5.75\left(\mathrm{mg} \mathrm{L}^{-1}\right)$ which is shown Table 1. The highest value $(5.75 \pm 0.49)$ of dissolved oxygen was recorded in the month of June and the lowest value $(4.26 \pm 0.07)$ was recorded in the month of September.

pH: Water $\mathrm{pH}$ is another important physical factor in any type of water body. Which is determined by using a direct reading digital $\mathrm{pH}$ meter (HANNA instruments, HI 96107 , made in Italy) on the spot. The ranges of $\mathrm{pH}$ were varied between 6.8-7.6 at different location in the selected study area. The highest value was determined (7.6 \pm 0.14$)$ in the month of April and the lowest value (6.8 \pm 0.00 )was in the month of May which is shown in the Table 1.

Alkalinity: Alkalinity was determined by using alkalinity test kit (HANNA Instruments, made in Romania). The ranges of alkalinity were recorded between 77.5-125.0 in different months during the study period in the selected area. The highest values of alkalinity $(125.0 \pm 21.12)$ were measured in the month of April and the lowest value was $77.5 \pm 6.36$ in the month of August which is shown Table 1.

Hardness: Hardness was determined directly by using Hardness test Kit (HANNA Instruments, made in Romania). The ranges of hardness were varied between 76-101.5 in different months during the investigation area. The highest values $(101.5 \pm 23.33)$ of hardness were observed in the month of April and the lowest values (76.0 \pm 8.49 ) in the month of August that are shown in the Table 1.

Table 1: Physico-chemical parameter are shown in different month

\begin{tabular}{lllllllll}
\hline Parameters & April & May & June & July & August & September & October & Mean \pm SD \\
\hline Temperature $\left({ }^{\circ} \mathrm{C}\right)$ & $28.0 \pm 1.41$ & $29.0 \pm 0.00$ & $31.5 \pm 0.71$ & $32.0 \pm 1.41$ & $29.0 \pm 1.41$ & $29.5 \pm 0.71$ & $26.5 \pm 0.71$ & $29.35 \pm 1.68$ \\
Transparency $(\mathrm{cm})$ & $36.0 \pm 2.81$ & $34.5 \pm 9.19$ & $31.5 \pm 0.71$ & $33.0 \pm 5.6$ & $36.0 \pm 1.06$ & $42.0 \pm 5.66$ & $44.0 \pm 1.41$ & $36.71 \pm 3.8$ \\
Dissolved Oxygen $\left(\mathrm{mg} \mathrm{L}^{-1}\right)$ & $5.15 \pm 0.07$ & $4.4 \pm 0.14$ & $5.75 \pm 0.49$ & $4.65 \pm 0.35$ & $5.7 \pm 0.21$ & $4.26 \pm 0.07$ & $4.40 \pm 0.07$ & $4.90 \pm 1.7$ \\
pH & $7.6 \pm 0.14$ & $6.8 \pm 0.00$ & $7.3 \pm 0.00$ & $6.9 \pm 0.00$ & $7.14 \pm 0.07$ & $7.22 \pm 0.00$ & $7.43 \pm 0.14$ & $7.19 \pm 0.7$ \\
Alkalinity $\left(\mathrm{mg} \mathrm{L}^{-1}\right)$ & $125.0 \pm 21.12$ & $86.5 \pm .3 .36$ & $92.5 \pm 31.2$ & $99.5 \pm 31.82$ & $77.5 \pm 6.36$ & $89.5 \pm 10.61$ & $95.5 \pm 10.61$ & $95.14 \pm 17.19$ \\
Hardness $\left(\mathrm{mg} \mathrm{L}^{-1}\right)$ & $101.5 \pm 23.33$ & $96 \pm 6.36$ & $78.5 \pm 4.24$ & $82.5 \pm 4.24$ & $76.0 \pm 8.49$ & $92.5 \pm 2.12$ & $86 \pm 10.61$ & $87.57 \pm 1.17$ \\
Nitrate-N $\left(\mathrm{mg} \mathrm{L}^{-1}\right)$ & 8.41 & 11.23 & 9.89 & 10.11 & 14.27 & 12.51 & 8.68 & $10.72 \pm 2.27$ \\
Ammonia $\left(\mathrm{mg} \mathrm{L}^{-1}\right)$ & $0.09 \pm 0.35$ & $0 . .15 \pm 0.00$ & $0.10 \pm 0.35$ & $0.08 \pm 0.35$ & $0.05 \pm 0.07$ & $0.7 \pm 0.14$ & $0.09 \pm 0.02$ & $0.18 \pm 0.08$ \\
\hline
\end{tabular}




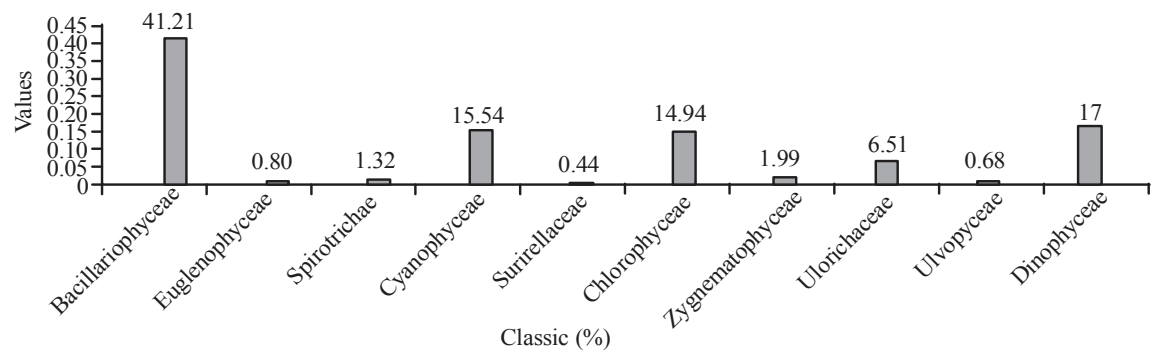

Fig. 1: Percentage of Phytoplankton abundance

Nitrate: Nitrate is another type of physical parameter which was measured by using a Nitrate test kit ( HANNA Instruments, made in Romania). The ranges of Nitrate were measured between 8.41-14.27 in different months and the highest values was 14.27 in the month of August and the lowest value was 8.41 in the month of April which is shown in the Table 1.

Ammonia: Ammonia has a great effect any type of water body. The ranges of ammonia varied between 0.05 to 0.15 in different months during the study period. The highest mean values $(0.15 \pm 0.00)$ of ammonia were recorded in the month of May and the lowest values $(0.05 \pm 0.07)$ were recorded in the month of August that are shown in the Table 1.

Phytoplankton is very essential for primary production. Fish and other aquatic organisms are depends on primary production. Abundance of phytoplankton that may vary from time to time and water body (Fig. 1). Generally samples are collected at different time, different location. In our study area it is visible that Bacillariophyceae (41.21\%), Euglenophyceae (0.80\%), Spirotrichea (1.32\%), Cyanophyceae (15.54\%), Surirellaceae (0.44\%), Chlorophyceae (14.94\%), Zygnematophyceae (1.99\%), Ulotrichaceae (6.51\%), Ulvophyceae $(0.68 \%)$ and Dinophyceae (17\%). Our findings are more or less similar to other researchers. The findings of this study are in agreement with the findings of Hossain et al..$^{[15]}$ and Verma and Shukla ${ }^{[16]}$ recorded 30 genera of phytoplankton from Kamala Nehru Tank, Muzaffarnagar, India while Hossain found 17 genera belonging to Cyanophyceae (5 classes, 34.47\%), Bacillariophyceae $(3,13.87 \%)$, Cyanophyceae (5, $34.48 \%$ ), Euglenophyceae $(3,10.68 \%)$ and Dinophyceae $(6.50 \%)$ from earthen fish pondss within the Rajshahi region, Bangladesh. From study analysis, 16 phytoplankton genera are recorded under 4 groups. But among of them Fragillaria (22.02\%) is the highest rate and surirella $(0.74 \%)$ has the lowest rate.

Zooplankton also has a great significance role on water body for maintaining the ecosystem and keep balance. Abundance of zooplankton mainly depends up on the availability of food and temperature on phytoplankton. But zooplankton also may vary from seasonal fluctuation.

Zooplankton affects lake ecosystem processes by grazing on phytoplankton, recycling nutrients and organic material and serving as prey for both vertebrate and invertebrate planktivores. In the majority of lakes phosphorus availability limits the algal production ${ }^{[17]}$ but see $^{[18]}$ which in turn determines the level of secondary production and affects also zooplankton species diversity ${ }^{[19,20]}$. As primary production increases, the quantity of food for zooplankton increases but its quality frequently deteriorates ${ }^{[21]}$. At the same time the abundance of planktivore fish increases as primary production is enhanced $^{[22,23]}$ but see Mehner et al. ${ }^{[24]}$ Predation has a greater impact on zooplankton communities in the nutrient poor ecosystems ${ }^{[25,26]}$ where top-down factors are more important than bottom-up factors. In general, total zooplankton biomass increases with increasing eutrophication but the size structure of zooplankton communities is often independent of lake trophy ${ }^{[27]}$.

Inter relationship between phytoplankton and zooplankton: Phytoplankton and zooplankton has a diverse relationship in the water body. Zooplankton abundance depends on phytoplankton. If increasing the abundance of zooplankton at a certain rate, the productivity of phytoplankton rate will be decreased in water body and vice versa. The zooplankton grazing pressure could help the change in dominance of phytoplankton and. Moreover, Ismael and Abdel-Aziz ${ }^{[28]}$ reported Spirulina as prey for cirripede larvae, the blue-green Oscillatoria spp. for the copepod P. parvus and $C$. meneghiniana for copepod nauplii, while Guergues found the diatom Nitzschia sp. in the gut of A. americanus. Finding results between two ponds during the study periods, its indicated that, phytoplankton is more dominant on zooplankton between pond $\mathrm{A}$ and pond $\mathrm{B}$ (Fig. 2, Table 2 and 3). Sometimes physic-chemical parameter has diversification effect on plankton abundance. Phytoplankton will decrease when increase in high temperature, salinity, nitrate, phosphorus in water body. 
Table 2: Abundance of plankton in fishponds (Phytoplankton)

\begin{tabular}{|c|c|c|c|c|c|c|c|}
\hline \multirow[b]{2}{*}{ Groups } & \multirow[b]{2}{*}{ Plankton name } & \multicolumn{2}{|c|}{ Pond A 2016} & \multicolumn{2}{|c|}{ Pond B 2017} & \multirow[b]{2}{*}{ Individual percentage } & \multirow[b]{2}{*}{ Total percentage } \\
\hline & & $\mathrm{SS}_{1}$ & $\mathrm{WS}_{1}$ & $\mathrm{SS}_{2}$ & $\mathrm{WS}_{2}$ & & \\
\hline \multirow[t]{15}{*}{ Bacillariophyceae } & Navicula & +++++ & + & ++ & ++++ & 3.30 & 41.21 \\
\hline & Bacteriastrumsp & ++ & - & ++++ & +++ & 4.14 & \\
\hline & Cyclotellasp & + & - & +++ & - & 1.08 & \\
\hline & Biddulphiasp & - & +++ & + & - & 0.60 & \\
\hline & Bacillariasp & +++ & - & ++ & + & 0.80 & \\
\hline & Melosirasp & - & +++ & - & ++ & 0.40 & \\
\hline & Gyrosigmasp & + & ++ & + & +++ & 0.95 & \\
\hline & Cymbellasp & - & - & +++ & - & 1.62 & \\
\hline & Thalassipthrixsp & + & ++++ & - & ++ & 2.98 & \\
\hline & Strepthotheca & ++ & + & ++ & +++ & 2.10 & \\
\hline & Rhizosoleriasp & +++ & - & +++ & + & 2.51 & \\
\hline & Stepharopysissp & ++ & - & ++++ & + & 6.20 & \\
\hline & Fragillaria & ++++ & ++ & ++ & - & 13.24 & \\
\hline & Tabellaria & - & + & - & +++ & 0.62 & \\
\hline & Nitzschia & ++ & + & + & +++ & 0.67 & \\
\hline Euglenophyceae & Euglena & +++ & - & ++ & - & 0.80 & 0.80 \\
\hline Spirotrichea & Codonela & - & +++ & +++ & + & 1.32 & 1.32 \\
\hline \multirow[t]{4}{*}{ Cyanophyceae } & Anabaena sp. & - & + & +++ & +++ & 2.54 & 15.54 \\
\hline & Nostoc sp. & ++++ & ++ & - & ++ & 3.24 & \\
\hline & Oscillatoria & +++ & ++ & ++++ & + & 7.93 & \\
\hline & Aphanizomenon & ++ & - & + & +++ & 1.83 & \\
\hline Surirellaceae & Surirella & - & ++ & + & +++ & 0.44 & 0.44 \\
\hline \multirow[t]{2}{*}{ Chlorophyceae } & Closterium & ++ & + & +++ & - & 12.85 & 14.94 \\
\hline & Rhizoclonium sp. & - & +++ & ++ & + & 2.09 & \\
\hline Zygnematophyceae & Gonatozygon & - & +++ & ++ & - & 1.99 & 1.99 \\
\hline Ulotrichaceae & Ulothrix & ++++ & ++ & +++ & ++++ & 6.51 & 6.51 \\
\hline Ulvophyceae & Cladophora & ++ & - & + & +++ & 0.68 & 0.68 \\
\hline \multirow[t]{3}{*}{ Dinophyceae } & Gymnodiumsp & +++ & + & +++ & ++ & 5.10 & 17 \\
\hline & Dinophysissp & ++++ & ++ & - & ++++ & 10.69 & \\
\hline & Ceratiumsp & - & +++ & + & ++ & 0.73 & \\
\hline
\end{tabular}

$\mathrm{SS}_{1}=$ Summer Season1; $\mathrm{WS}_{1}=$ Winter Season $1 \mathrm{SS}_{2}=$ Summer Season ${ }_{2} ; \mathrm{WS}_{2}=$ Winter Season $2:(-): 0$ cell m${ }^{-3} ;(+): 1-100$ cell m m $^{-3} ;(++): 100-1000$ cell $\mathrm{m}^{-3}$; (+++): 1001-10000 cell m

Table 3: Abundance of plankton in fishponds (Zooplankton)

\begin{tabular}{|c|c|c|c|c|c|c|c|}
\hline \multirow[b]{2}{*}{ Groups } & \multirow[b]{2}{*}{ Plankton name } & \multicolumn{2}{|c|}{ Pond A 2016} & \multicolumn{2}{|c|}{ Pond B 2017} & \multirow[b]{2}{*}{ Individual percentage } & \multirow[b]{2}{*}{ Total percentage } \\
\hline & & $\mathrm{SS}_{1}$ & $\mathrm{WS}_{\perp}$ & $\mathrm{SS}_{2}$ & $\mathrm{WS}_{2}$ & & \\
\hline \multirow[t]{2}{*}{$\overline{\text { Copepoda }}$} & Cyclops & +++ & - & ++ & - & 28.80 & 40.08 \\
\hline & Diaptomus & +++ & ++++ & + & ++++ & 11.28 & \\
\hline Maxillopoda & Nauplius & - & +++ & +++ & + & 38.83 & 38.83 \\
\hline Malacostraca & Crab larvae & +++ & ++ & ++++ & +++ & 16.29 & 16.29 \\
\hline \multirow[t]{2}{*}{ Branchiopoda } & Daphnia sp. & +++ & ++ & +++ & ++ & 3.77 & 4.8 \\
\hline & Moina & ++ & - & +++ & + & 1.03 & \\
\hline
\end{tabular}

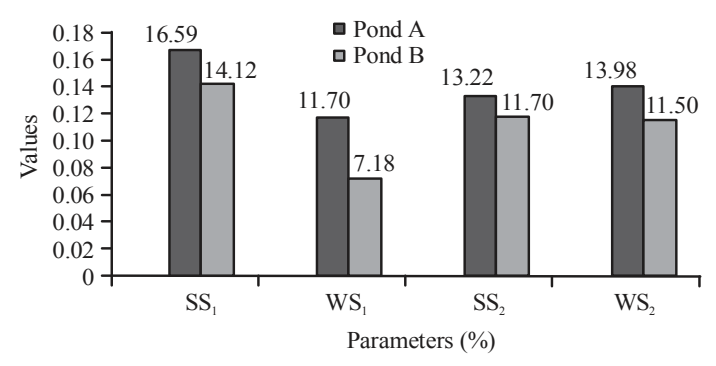

Fig. 2: Abundance of plankton between two ponds

\section{CONCLUSION}

The obtained results show that physic-chemical parameter has a great influence over the plankton community. Their abundance, growth and distribution that may vary on that parameter. No single factor is responsible for this variability. However, temperature, sunlight exposure period, sunlight penetration, water $\mathrm{pH}$, wind, transparency, seasonal variations, water characteristics, nutrient enrichment and prey-predator may be related to variable changes in the plankton distribution and their abundance in ponds' water. Those parameters also depend on the seasonal fluctuation. So, they are inter connected with each other's. All those information are very useful for further research activities and introduced as a main foundation of related study criteria in this Patuakhali district, Bangladesh.

\section{ACKNOWLEDGEMENTS}

The researchers are extremely thankful for the supporting and laboratory facilities by the Chairman, 
Department of Fisheries Management, Patuakhali Science and Technology University, Bangladesh and also for supporting the provide the information undertake this successful study.

\section{REFERENCES}

01. Bhuiyan, A.S., Q. Nahar and M.N. Islam, 1997. Physico-chemical condition in relation to meteorological condition of a fish pond in Rajshahi University. J. Zool. Rajshahi Univ., 16: 85-88.

02. Edward, J.B. and A.A.A. Ugwumba, 2010. Development trends and evaluation of Egbe Reservoir water nutrient status in Ekiti State, Nigeria. J. Life Sci., 4: 7-16.

03. Battish, S.K., 1992. Freshwater Zooplanktons of India. Oxford and IBH Publishing Co. Ltd., New Delhi.

04. Fakruzzaman, M., A.H. Chowdhury, S. Naz and M. Zaman, 2001. Zooplankton of some fishponds in Barind Tract in relation to its physico-chemical variables. Univ. J. Zool. Rajshahi Univ., 20: 75-80.

05. Biswas, A., 1993. Limnology of three fishponds in rajshahi hatchery. M.Sc. Thesis, Deptartment of Botany, University of Rajshahi, Rajshahi, Bangladesh.

06. Rahman, M.S., M.Y. Chowdhury, A.K.M. Aminul-Haque and M.S. Haq, 1982. Limnological studies of four ponds. Bangladesh J. Fish., 25: 25-35.

07. Mumtazuddi, M.N. and M.S. Rahman, 1982. Limnological studies of four selected ponds at the aquaculture expteriment satation, Mymensingh. Bangladesh J. Fish., 2: 83-90.

08. Prasad, B.B. and R.B. Singh, 2003. Composition, abundance and distribution of phytoplankton and zoobenthos in a tropical water body. Natl. Environ. Pollut. Technol., 2: 255-258.

09. Shafi, M. and G. Mustafa, 1976. Observation on some aspects of the biology of the Climbing perch, Anabas testudineus (Bloch). Bangladesh J. Zool., 4: 21-28.

10. Mustafa, G. and A.T.A. Ahmed, 1979. Foods of Notopterus notopterus (Pallas). Bangladesh J. Zoo., 7: 7-14.

11. Ali, M.M. and A. Islam, 1981. Studies on the food of Labeo rohita (Ham): Catla catla (Ham) and Cirrhina mrigala (Ham) grown at the Bangladesh Agricultural University fish farm. Proceedings of the 3rd International Zoological Conference, March 15-17, 1981, ZBS, Dhaka, Bangladesh, pp: 152-158.

12. Smail, M., H. Rahman, S. Ali and K.H. Ahmed, 1984. Studies on limnology and some aspects of biology of Oreochromis nilotica (L) in a pond Jurain, Dhaka. Proceedings of the 4th International Zool Conference, August 16-25, 1984, Bangladesh, pp: 97-105.
13. Ali, M., A. Salam, A. Islam and S.M. Rahmatullah, 1984. A study on the food and feeding habits of Rohtee cotio (Ham) in a pond of Bangladesh Agricultural University, Mymensingh. Proceedings of the 4th International Zool Conference, August 16-25, 1984, Bangladesh, South Asia, pp: 29-36.

14. APHA., 1975. Standard Methods for the Examination of Water and Wastewater. 14th Edn., American Public Health Association, Washington, DC. USA.,.

15. Hossain, M.Y., S. Jasmine, A.H.M. Ibrahim, Z.F. Ahmed and J. Ohtomi et al., 2007. A preliminary observation on water quality and plankton of an earthen fish pond in Bangladesh: Recommendations for future studies. Pak. J. Biol. Sci., 10: 868-873.

16. Verma, S.R. and G.R. Shukla, 1970. The physico-chemical conditions of Kamala Nehru Tank, Muzaffarnagar (UP) in relation to the biological productivity. Environ. Health, 12: 110-128.

17. Hecky, R.E. and P. Kilham, 1988. Nutrient limitation of phytoplankton in freshwater and marine environments: A review of recent evidence on the effects of enrichment. Limnol. Oceanogr., 33: 796-822.

18. Elser, J.J., M.E.S. Bracken, E.E. Cleland, D.S. Gruner and W.S. Harpole et al., 2007. Global analysis of nitrogen and phosphorus limitation of primary producers in freshwater, marine and terrestrial ecosystems. Ecol. Lett., 10: 1135-1142.

19. Dodson, S.I., S.E. Arnott and K.L. Cottingham, 2000. The relationship in lake communities between primary productivity and species richness. Ecology, 81: 2662-2679.

20. Hessen, D.O., T. Andersen and B.A. Faafeng, 1995. Replacement of herbivore zooplankton species along gradients of ecosystem productivity and fish predation pressure. Can. J. Fish. Aquat. Sci., 52: 733-742.

21. Sommer, U., Z.M. Gliwiez, W. Lampert and A. Duncan, 1986. The PEG-Model of seasonal succession of plankton events in freshwater. Arch. Hydrobiol., 106: 433-471.

22. Jeppesen, E., J.P. Jensen, M. Søndergaard, T. Lauridsen and R. Landkildehus, 2000. Trophic structure, species richness and biodiversity in Danish lakes: Changes along a phosphorus gradient. Freshwater Ecol., 4: 201-218.

23. Olin, M.M., J. Ruuhljarvi, M. Kurkilahti, P. Ala-Opas and O. Ylonen, 2002. Fish community structure in mesotrophic and eutrophic lakes of southern Finland: The relative abundances of percids and cyprinids along a trophic gradient. J. Fish Biol., 60: 593-612.

24. Mehner, T., M. Diekmann, U. Bramick and R. Lemcke, 2005. Composition of fish communities in German lakes as related to lake morphology, trophic state, shore structure and human-use intensity. Freshwater Biol., 50: 70-85. 
25. Carpenter, S.R. and J.F. Kitchell, 1987. The temporal scale of variance in limnetic primary production. Am. Nat., 129: 417-433.

26. Finlay, K., B.E. Beisner, A. Patoine and B. Pinel-Alloul, 2007. Regional ecosystem variability drives the relative importance of bottom-up and top-down factors for zooplankton size spectra. Can. J. Fish. Aquat. Sci., 64: 516-529.
27. Pace, M.J., 1986. An empirical analysis of zooplankton community size structure across lake trophic gradients. Limnol. Oceanogr., 31: 45-55.

28. Ismael, A.A. and N.E. Abdel-Aziz, 2003. Selective grazing on phytoplankton in El-Dekhaila Harbour (Alexandria). Mar. Life, 13: 21-30. 